\title{
The Azores Countercurrent
}

\author{
REINER ONKEN \\ Institut fuir Meereskunde, Kiel, Germany
}

(Manuscript received 7 April 1992, in final form 1 September 1992)

ABSTRACT

\begin{abstract}
New light is shed on Worthington's concept of the North Atlantic circulation, postulating the existence of two anticyclonic gyres. This concept, which seems to have been laid to rest in the last decade, has now been reinforced by the results of a simple linear Sverdrup circulation model yielding a band of westward transport all across the North Atlantic at about the Azores latitude. This narrow band is called the Azores Countercurrent $(\mathrm{AzCC})$ and matches the position of westward flow required by Worthington's "northern gyre." An anomaly in the meridional change of the wind-stress curl in the eastern North Atlantic has been identified as the driving mechanism.

A comparison with observations shows that the $\mathrm{AzCC}$ is verified in many analyses of historical datasets and synoptic surveys. A lack of the AzCC in other analyses is probably due to missing meridional sections, strong smoothing, and the superimposed Ekman flow close to the sea surface directed to the southeast. The AzCC has not been verified in low-resolution general circulation models applying simplified wind-stress fields and large friction coefficients, but there is evidence for its existence in recent high-resolution models driven by realistic wind stresses.

Based on these findings, a new pattern for the wind-driven upper ocean circulation of the midlatitude North Atlantic is presented.
\end{abstract}

\section{Introduction}

The classical pattern of the upper-ocean general circulation of the northern and central North Atlantic consists of two basin-scale gyres-the cyclonic subpolar and the anticyclonic subtropical gyres. According to Dietrich et al. (1980), the entire subtropical recirculation is fed by the Gulf Stream (GS), which branches southeast of the Grand Banks into the North Atlantic Current (NAC) and a southern part recirculating into the Sargasso Sea. In contrast, Worthington (1962) and Worthington et al. (1976) suggested a system of two separate gyres in the western North Atlantic, the subtropical gyre and the "northern gyre." Worthington concluded that the GS and its recirculation in the Sargasso Sea are major elements of the subtropical gyre, whereas the NAC is part of the northern gyre. Recent observations (Clarke et al. 1980; Krauss 1986; Krauss et al. 1987, 1990) reconfirmed the branching of the GS into the NAC turning to the northeast while a southern branch partly feeds the Azores Current (AC) (Käse and Siedler 1982; Käse et al. 1985; Gould 1985; Klein and Siedler 1989) and partly the Sargasso Sea circulation. But does this mean that Worthington's concept was completely wrong? It is suggested here that

Corresponding author address: Dr. Reiner Onken, Institut für Meereskunde, Universitat Kiel, Düsternbrooker Weg 20, W 2300, Kiel 1, Germany. proof has only been provided for the GS and the NAC to be connected, but the existence of two gyres in the interior of the North Atlantic away from the western boundary region has not been disproved.

If one applies the simple Sverdrup relation, evidence is found for a double-gyre pattern in the midlatitude North Atlantic. The positions of the gyre boundaries agree well with Worthington's concept.

\section{Model description}

Spherical coordinates will be used. The steady linearized equation for the vertically integrated meridional velocity (Sverdrup equation) is given by

$$
V(\lambda, \varphi)=\frac{1}{\rho \beta}(\nabla \times \pi)_{z} .
$$

The vertically integrated zonal velocity $U$ can be computed by integrating the continuity equation

$$
\frac{\partial U}{\partial \lambda}=-\frac{\partial}{\partial \varphi}(V \cos \varphi)
$$

from the eastern boundary, assuming zero normal velocity there:

$$
U\left(\lambda, \varphi_{0}\right)=-\frac{\partial}{\partial \varphi} \int_{\lambda_{E}}^{\lambda} V \cos \varphi d \lambda^{\prime}
$$

The meanings of abbreviations and symbols used above are 
$\beta=\frac{2}{R} \Omega \cos \varphi$

meridional gradient of Coriolis parameter;

$(\nabla \times \tau)_{z}=\frac{1}{R \cos \varphi}\left[\frac{\partial \tau_{\varphi}}{\partial \lambda}-\frac{\partial}{\partial \varphi}\left(\tau_{\lambda} \cos \varphi\right)\right]$

vertical component of the wind-stress curl; and

$\mathbf{U}=(U, V)=\int_{z=-H}^{0} \mathbf{u} d z$

vertically integrated horizontal velocity

$H \quad$ water depth $=$ const

$R$ earth radius $=6371 \mathrm{~km}$

$u$ zonal velocity

$v$ meridional velocity

u horizontal velocity

$z \quad$ vertical coordinate, increasing upward

$\varphi \quad$ latitude $=0$ at the equator, increasing northward

$\lambda$ longitude $=0$ at the Greenwich meridian, increasing eastward

$\lambda_{E} \quad$ longitude of eastern boundary

$\lambda^{\prime} \quad$ longitude (integration variable)

$\rho \quad$ density of seawater $=1000 \mathrm{~kg} \mathrm{~m}^{-3}$

$\tau_{\lambda} \quad$ zonal wind stress

$\tau_{\varphi} \quad$ meridional wind stress

$\varphi_{0}$ fixed latitude

$\Omega=7.27 \times 10^{-5} \mathrm{~s}^{-1}$ angular frequency of the earth.

In the above equations the assumptions have been made that there is no horizontal friction and that the horizontal stress and the vertical velocity are zero at $z$ $=-H$.

The vanishing vertical velocity at the bottom allows introduction of a streamfunction, $\Psi$, for the horizontal volume transport, resulting in the following equations for the vertically integrated velocities:

$$
\begin{aligned}
& U=-\frac{1}{R} \frac{\partial \Psi}{\partial \varphi} \\
& V=\frac{1}{R \cos \varphi} \frac{\partial \Psi}{\partial \lambda} .
\end{aligned}
$$

The model basin representing the North Atlantic is limited by zonal walls at $\varphi=0^{\circ}$ (equator) and $\varphi$ $=66^{\circ} \mathrm{N}$. The meridional boundaries are given by the 200-m-depth contour. The passages through the Antilles Archipelago are closed. A $2^{\circ} \times 2^{\circ}$ grid is used. The wind stress of Hellerman and Rosenstein (1983, later referred to as HR) is applied.

\section{Model results}

The volume transport streamfunction outside the western boundary regime is displayed in Fig. 1. The subtropical anticyclonic gyre is recognized as extending from about $15^{\circ}$ to $50^{\circ} \mathrm{N}$. To the north the cyclonic

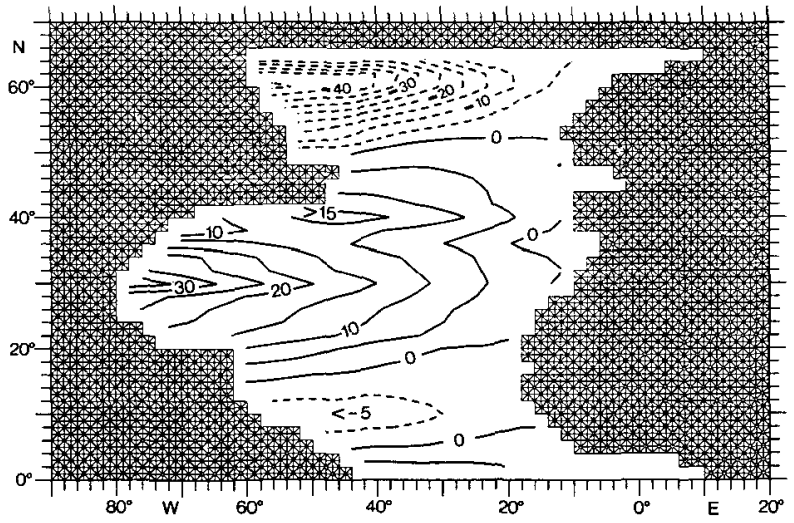

FIG. 1. The Sverdrup volume transport streamfunction in Sverdrups $\left(1 \mathrm{~Sv} \equiv 10^{6} \mathrm{~m}^{3} \mathrm{~s}^{-1}\right)$. Contour interval is $5 \mathrm{~Sv}$.

subpolar gyre is found, and another cyclonic gyre exists in the tropics between about $5^{\circ}$ and $15^{\circ} \mathrm{N}$. A closer look reveals that the pattern corresponding to the subtropical gyre actually consists of two anticyclonic circulation cells separated at about $36^{\circ} \mathrm{N}$ latitude. To the north of this latitude the zonal transport is directed westward, and to the south an eastward component can be found. To elucidate this fact, the volume transport

$$
\mathrm{U}_{\mathrm{Vol}}=(U R \Delta \varphi, V R \cos \varphi \Delta \lambda)
$$

is additionally given as a vector plot in Fig. 2, where $\Delta \varphi=\Delta \lambda=2 \pi / 180$ is the grid interval. Now it can be seen more clearly that the southern boundary of the northern anticyclonic gyre is marked by a band of westward transport between $36^{\circ}$ and $40^{\circ} \mathrm{N}$. At $36^{\circ} \mathrm{N}$ the zonal transport nearly vanishes and the enhanced eastward transport at $35^{\circ} \mathrm{N}$ is part of the southern anticyclonic gyre. In Fig. 3 the zonal volume transport is shown in 2-degree intervals along the $40^{\circ} \mathrm{W}$ meridian, the corresponding meridionally integrated transports starting with zero at the equator. Ignoring the westward transport between the equator and $4^{\circ} \mathrm{N}$, Fig. $3 \mathrm{~b}$ shows the three main gyres (subpolar, subtropical, tropical) separated by zero line crossings. The subtropical gyre is limited by the $16^{\circ}$ and $50^{\circ} \mathrm{N}$ latitude circles. Eastward transport occurs in two bands between $40^{\circ}$ and $48^{\circ} \mathrm{N}$ and between $30^{\circ}$ and $36^{\circ} \mathrm{N}$ (cf. also Fig. 3a). The total transport is $16.1 \mathrm{~Sv}\left(1 \mathrm{~Sv} \equiv 10^{6} \mathrm{~m}^{3} \mathrm{~s}^{-1}\right)$ in the northern band and $6.9 \mathrm{~Sv}$ in the southern band. From the sum of $23 \mathrm{~Sv}$ an amount of $17.1 \mathrm{~Sv}$ is recirculated in a broad band between $16^{\circ}$ and $30^{\circ} \mathrm{N}$, and the remainder of about $5.9 \mathrm{~Sv}$ is concentrated in a narrow band between $36^{\circ}$ and $40^{\circ} \mathrm{N}$ (cf. Fig. 3a). Thus, in the eastern basin (i.e., east of $40^{\circ} \mathrm{W}$ ) about $25 \%$ of the subtropical recirculation occurs in the northern part of the double gyre pattern.

What is the reason for the narrow band of westward transport? One might think that this anomaly of zonal transport is due to the path of the $U$-integral (3) mod- 


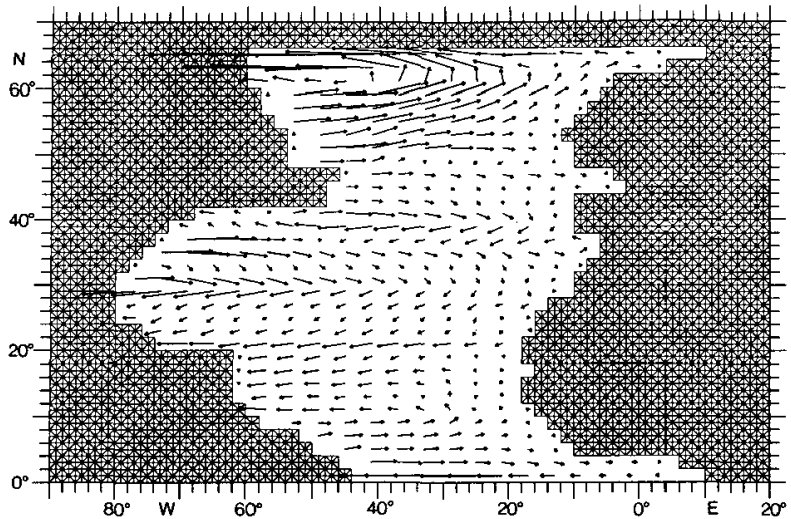

FIG. 2. The Sverdrup volume transport as a vector plot. Only every second vector in the zonal rows is plotted. The length of the arrow tails is proportional to the transport. For transport numbers compare with Fig. 1.

ified by the shape of the eastern coastline. However, the anomaly does not disappear in the case of a straight eastern coastline. Substitution of ( 1 ) into (3) yields

$$
U\left(\lambda, \varphi_{0}\right)=-\frac{R}{2 \Omega \rho} \frac{\partial}{\partial \varphi} \int_{\lambda_{E}}^{\lambda}(\nabla \times \mathbf{r})_{z} d \lambda^{\prime} .
$$

Thus, it is the integrated meridional gradient of the wind-stress curl that determines the strength and direction of the zonal flow. A contour plot of $\partial(\nabla \times \mathbf{r})_{z}$ / $\partial \varphi$ (Fig. 4) reveals that the negative values to the west of the Strait of Gibraltar lead to westward transport in the interior of the ocean. It should be mentioned that according to HR (their Fig. 10) this seems to be a feature that is present throughout the year. Thus, it cannot be inferred that the climatological wind data for one season exhibits extremely anomalous wind conditions.

\section{Verification}

The westward transport mentioned above is found at the approximate latitude of the Azores; hence we call it the "Azores Countercurrent" (AzCC) in contrast to the "Azores Current" (AC) (cf. Gould 1985; Stramma and Müller 1989). In order to verify whether the AzCC really exists, the model results will be compared with results from observations. Because it is believed that the major part of the Sverdrup transport occurs in the upper ocean (cf. Leetmaa et al. 1977), the comparisons will be restricted to the upper 1000 dbar layer.

Evidence for the existence of the $\mathrm{AzCC}$ is found in several publications presenting results from analyses of historical hydrographic datasets of the central and eastern North Atlantic. Defant's (1961, Fig. 271) map of absolute topography of the sea surface shows an anticyclonic feature west of the Azores that contributes to westward currents between $36^{\circ}$ and $40^{\circ} \mathrm{N}$. Maillard's (1984) dynamic height calculations for the 600-dbar level (her Fig. 3) revealed a narrow band of westward flow at about $38^{\circ} \mathrm{N}$. No such westward flow can be seen at the 50-dbar level (her Fig. 2). Klein and Siedler (1989) computed geostrophic volume transports for depth ranges of $0-200 \mathrm{~m}$ and $0-800 \mathrm{~m}$. At least in their summer data, westward transport of about 1-1.5 Sv (less pronounced in the $0-200-\mathrm{m}$ data) is evident to the west and to the east of the Azores Archipelago at about $38^{\circ} \mathrm{N}$ (Fig. 5), a feature that seems to be robust-
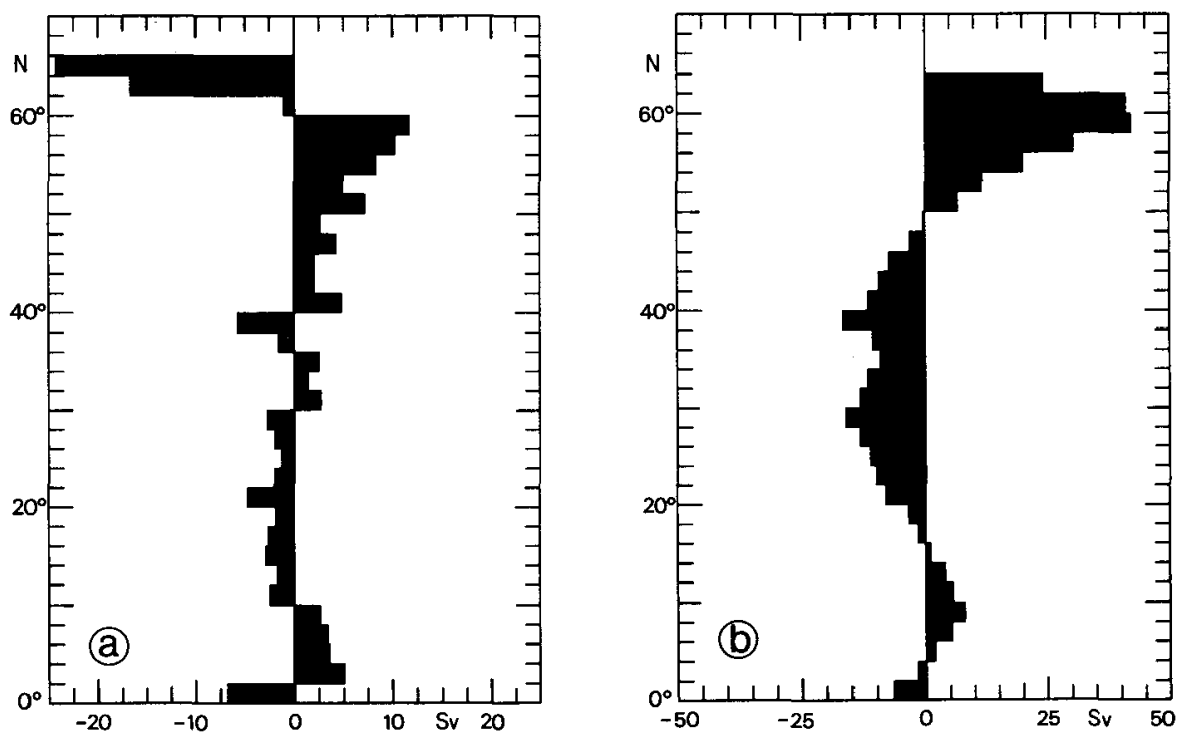

Fig. 3. (a) The zonal volume transport along the $40^{\circ} \mathrm{W}$ meridian in Sv. (b) The northwardintegrated volume transport at the same meridian. The integration starts at the equator. 


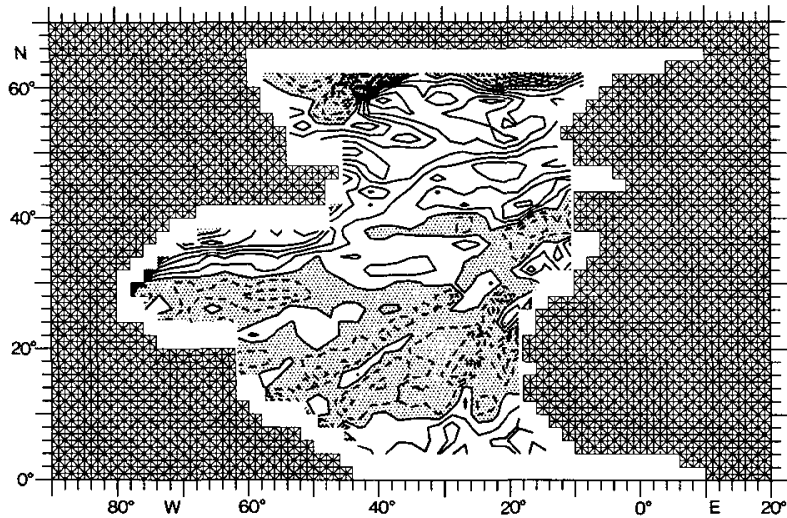

FIG. 4. The meridional derivative of the wind-stress curl $\partial(\nabla$ $X \mathbf{r})_{z} / \partial \varphi$. Shaded areas and dashed lines mean negative values. The zero line is the first solid one. Contour interval is $5 \times 10^{-7} \mathrm{~N} \mathrm{~m}^{-3}$ $\mathrm{rad}^{-2}$.

to different choices of the level of no motion (their Fig. 9). Based on the same dataset, Stramma (1984a, Fig. 7) and Stramma and Isemer (1988, Fig. 3c) found westward transport east of the Azores in the annual mean data for the $200-800-\mathrm{m}$ depth range and in the summer data for the depth range $0-1500 \mathrm{~m}$.

The existence of the $\mathrm{AzCC}$ is also manifested by geostrophic transports derived from quasi-synoptic surveys of the density field. Unfortunately, the number of meridional sections that serve best for this purpose is very limited - the majority of trans-Atlantic sections are zonal. One of the first meridional sections in this area was presented by Defant (1936a). This section is located at about $42^{\circ} \mathrm{W}$ south of $35^{\circ} \mathrm{N}$ and on $30^{\circ} \mathrm{W}$ north of $40^{\circ} \mathrm{N}$. Between $35^{\circ}$ and $40^{\circ} \mathrm{N}$, it has a southwest-northeast orientation. Though Defant did not calculate geostrophic velocities, the large-scale zonal current patterns in the upper 1000-m layer can easily be related to the meridional density gradients (Beilage XLVIII). Increasing density to the north between $33^{\circ}$ and $36^{\circ} \mathrm{N}$ can be attributed to the eastward-flowing AC. Between $38^{\circ}$ and $41^{\circ} \mathrm{N}$ the isopycnal slope reverses, indicating westward flow of the AzCC. Two additional meridional sections in the central North Atlantic on either side of the Mid-Atlantic Ridge have been obtained during the TOPOGULF experiment (TOPOGULF Group 1986). Sy (1988) calculated geostrophic currents and cumulative transports and found westward flow between $38^{\circ}$ and $40^{\circ} \mathrm{N}$ in the eastern section at about $25^{\circ} \mathrm{W}$ (Fig. 6). The corresponding volume transport is approximately $15 \mathrm{~Sv}$. Nearly the same magnitude of transport can be found in the western section (about $35^{\circ} \mathrm{W}$ ), but here the maximum westward flow occurs at about $37^{\circ} \mathrm{N}$. More evidence for westward transport from meridional sections at about the Azores latitude can be found in Stramma (1984b, Fig. 5) and Stramma and Müller (1989, Figs. 3, 4). Unfortunately, these sections have been terminated in the center of the most interesting latitude band at $37^{\circ} \mathrm{N}$.

The above investigations are mainly restricted to the central North Atlantic. Information about the exten-

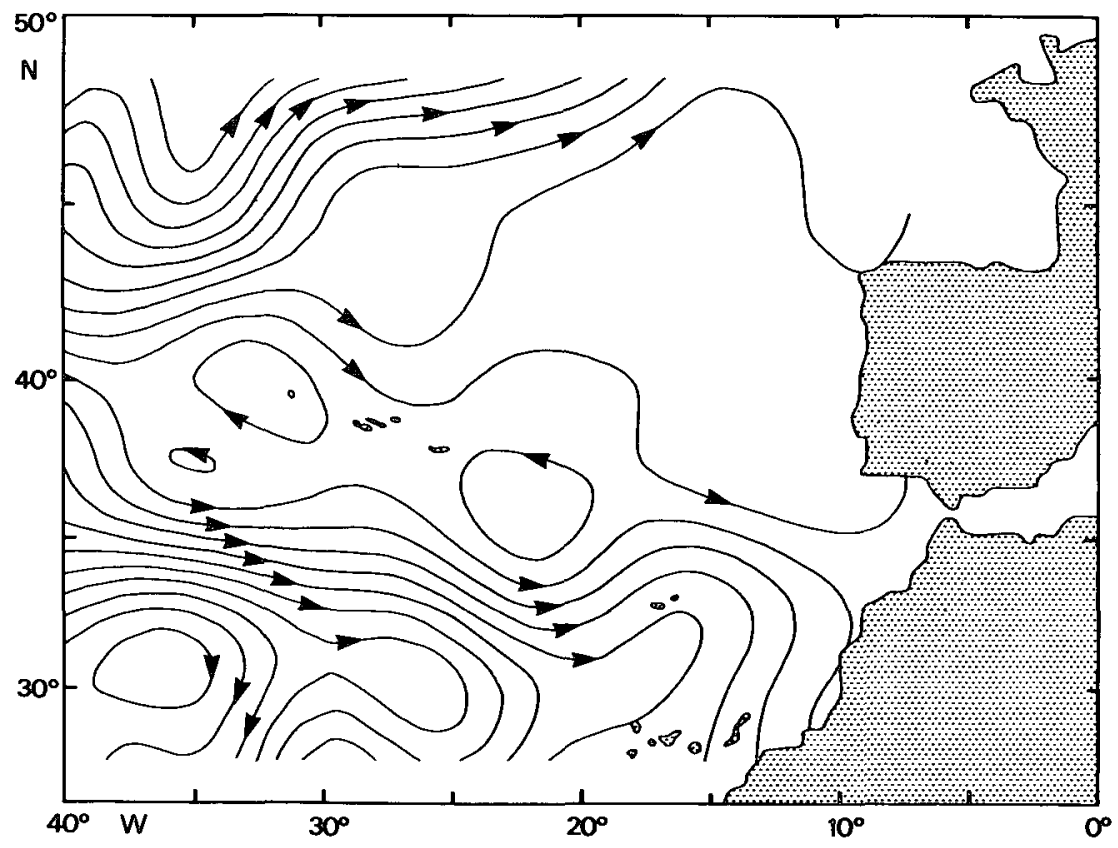

FIG. 5. The geostrophic summer volume transport in the 0-800-dbar layer derived from historical data. Contour interval is 1.5 Sv (after Klein and Siedler 1989). 


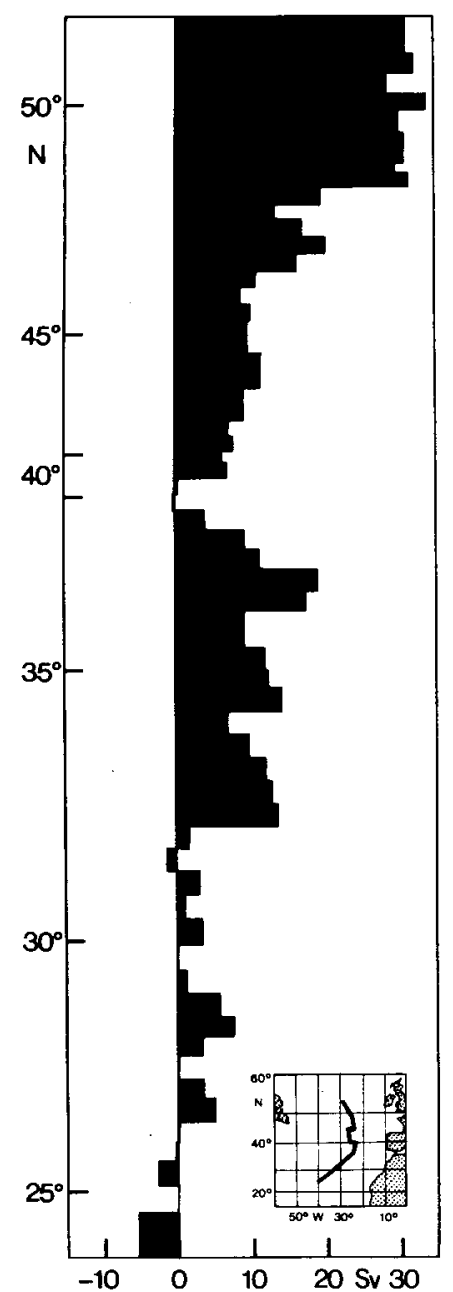

FIG. 6. The cumulative zonal volume transport perpendicular to a section along the eastern flank of the Mid-Atlầntic Ridge (after Sy 1988). The location of the section is shown in the inset.

sion of the AzCC into the western North Atlantic can be drawn from Worthington $(1962,1976)$, who computed geostrophic transports from a meridional section at about $50^{\circ} \mathrm{W}$ and two southwest-northeast sections located between $36^{\circ}$ and $39^{\circ} \mathrm{N}$ at $45^{\circ} \mathrm{W}$ (Worthington 1962 ) and between $37^{\circ}$ and $46^{\circ} \mathrm{N}$ at about $41^{\circ} \mathrm{W}$ (Worthington 1976). Though these sections have been obtained in different years, they are consistent with respect to a narrow, approximately $200-\mathrm{km}$ wide, band of westward flow between $38^{\circ}$ and $40^{\circ} \mathrm{N}$. This is an indication that the $\mathrm{AzCC}$ continues into the western Atlantic and feeds into the GS/NAC system, a conclusion that can also be drawn from Mann (1967, Fig. 15 ), who presented the schematic current system east of the Grand Banks based on geostrophic calculations. Westward transport of about $20 \mathrm{~Sv}$ occurs at about $40^{\circ} \mathrm{N}$, which he attributed to a large anticyclone centered at about $41^{\circ} \mathrm{N}, 42^{\circ} \mathrm{W}$ and a northwestward-turn- ing branch of the GS. The westward inflow and the position of this anticyclone has also been confirmed by Clarke et al. (1980) and Krauss et al. $(1978,1990)$ from independent surveys (Fig. 7).

Information on zonal currents can also be gained from direct current measurements. During the NEADS (North East Atlantic Dynamics Study) experiment several current meter moorings have been deployed east of the Mid-Atlantic Ridge, one of which (Site NEADS 2) was positioned at $38^{\circ} \mathrm{N}, 17^{\circ} \mathrm{W}$ for a duration of 533 days. For this mooring the flow statistics yield a mean zonal flow component of $1.2 \mathrm{~cm} \mathrm{~s}^{-1}$ to the west at a nominal depth of $750 \mathrm{~m}$ (Gould 1983). Current meter records deployed at about $40^{\circ} \mathrm{N}, 45^{\circ} \mathrm{W}$ in the depth range 500-600 m also suggest westward mean flow (Fofonoff and Hendry 1985), but these values are not statistically significant.

Somewhat conflicting evidence of the AzCC can also be found in basin-scale property distributions. Defant's (1936b) horizontal maps of temperature, salinity, and density suggest westward flow at about the Azores latitude, indicated by a tongue of cold, fresh and dense water extending far into the western Atlantic. This tongue is also visible in maps showing the distribution of pressure on isopycnals; for example, in Montgomery and Pollak (1942), who recompiled Defant's data, and in Kawase and Sarmiento (1985, Fig. 3), who derived these maps from more recent datasets. At the Azores longitude $\left(30^{\circ} \mathrm{W}\right)$ the tongue is centered at about $38^{\circ} \mathrm{N}$, but with progressing longitude the axis shifts south to about $35^{\circ} \mathrm{N}$. In contrast to these basin-scale distribution patterns, Worthington's (1962) regional map of oxygen

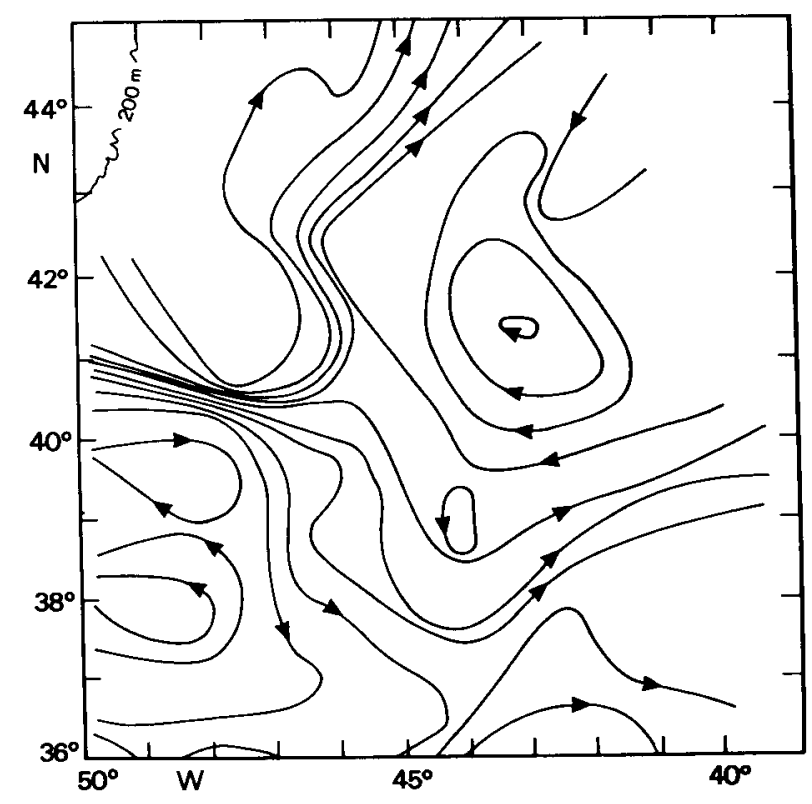

FIG. 7. Dynamic height anomaly at the sea surface relative to 2000 dbar in dyn $\mathrm{m}$. Contour interval is 0.1 dyn $\mathrm{m}$ (after Clarke et al. 1980). 


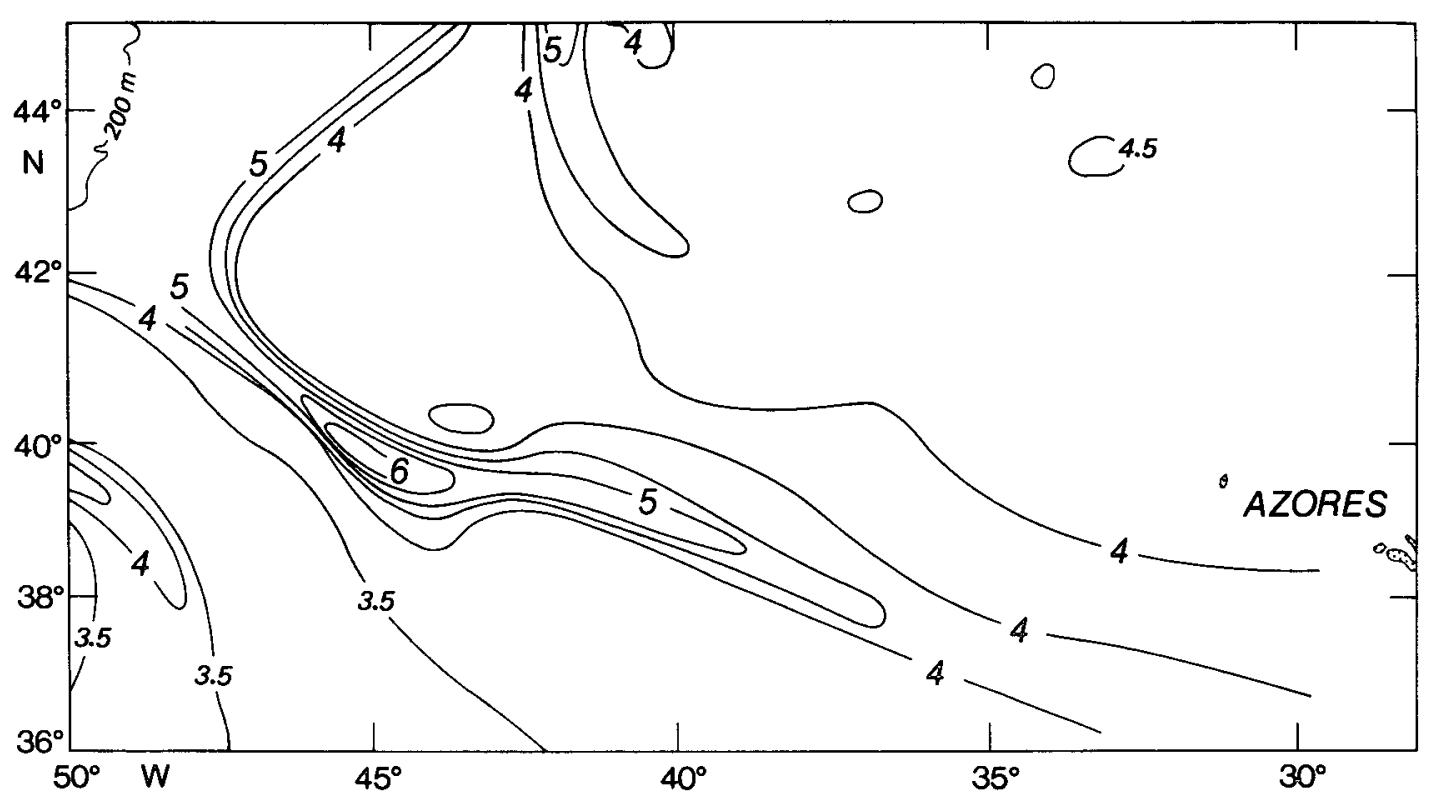

FIG. 8. Oxygen at the $10^{\circ} \mathrm{C}$ isotherm in $\mathrm{ml}^{-1}$ (after Worthington 1962).

distribution on the $10^{\circ} \mathrm{C}$ isothermal surface (redrawn in Fig. 8) suggests a flow directed to the west-northwest between the Azores and $47^{\circ} \mathrm{W}$. The oxygen distribution agrees remarkably well with the dynamic topography pattern displayed in Fig. 7, although both quantities are based on datasets from different years.

Evidence for the existence of the AzCC can also be drawn from high-resolution primitive equation models of the North Atlantic circulation. For the Canary Basin, Spall (1990, his Fig. 1a) displayed the transport streamfunction for the upper 800 -m layer. The structure and magnitude matches the Sverdrup transport remarkably well. Especially between $36^{\circ}$ and $40^{\circ} \mathrm{N}$, there is southwestward flow, the westward component of which increases with progressing distance from the eastern coast. Further indication for westward flow in this latitudinal range can be found in Treguier's (1992) North Atlantic model (her Fig. 3) and in the global models of Semtner and Chervin (1988, their Figs. 4 and 5) and Semtner and Chervin (1992, their Plates 1,3 , and 5). All of these models are driven by the HR wind stresses, and at least in low and moderate latitudes of the central and eastern Atlantic, the vertically integrated time-averaged volume transports reproduce the pattern derived from Sverdrup's relation to a high degree. This is also true for Böning's eddy-resolving primitive equation model (Böning 1992, personal communication; cf. also Böning et al. 1991a) driven by the IH wind-stress climatology (see below). However, even after averaging the volume transports in the upper (about 1000-m) layer, over five model years, the transport pattern west of $40^{\circ} \mathrm{W}$ at about the Azores latitude is still masked by eddy variability.

\section{Discussion and conclusions}

It was shown here that the linear Sverdrup relationship with climatological wind data yields westward volume transport all across the Atlantic Ocean between $36^{\circ}$ and $40^{\circ} \mathrm{N}$, which is caused by an anomaly of the meridional derivative of the wind-stress curl. At several longitudes between $17^{\circ}$ and $55^{\circ} \mathrm{W}$, the existence of the $\mathrm{AzCC}$ can be verified from historical data, from geostrophic calculations of one-time surveys, from direct current measurements, from the horizontal distribution of scalar quantities, and from high-resolution numerical models.

The feature is not completely consistent with basinscale maps of scalar quantities, which points to the possibility that the axis of the $\mathrm{AzCC}$ shifts southward by about 5 degrees with increasing western longitude. The mismatch is possibly due to lack of data around $40^{\circ} \mathrm{N}$ in Defant's (1936b) database west of the Azores and missing meridional sections; in Kawase and Sarmiento (1985), the next quasi-meridional section to the west of the Azores is at about $50^{\circ} \mathrm{W}$. There is no evidence for westward transport at the sea surface, which indicates that the $\mathrm{AzCC}$ is confined to the ocean interior. In Maillard (1984) the AzCC is only visible in the 600-dbar dynamic height field, but not in the 50-dbar map. Stramma's (1984a) volume transport calculations yield no westward transport in the layer 0-200 dbar (his Fig. 8). The AzCC is only evident in his volume transport integrated between 0 and $800 \mathrm{~m}$ (his Fig. 7). No such conclusion can be drawn from Klein and Siedler (1989), which is possibly due to their 
selection of contour interval. The absence of the $\mathrm{AzCC}$ in the surface layer is also consistent with mean velocities computed from surface-drifter trajectories (cf. Richardson 1983) and is probably due to the annual mean Ekman volume transport pointing to the southeast in this latitude belt (cf. Isemer and Hasse 1987, referred to as IH, Chart 199).

There are several studies of the circulation in this area, however, that do not show any evidence for the existence of the AzCC. Saunders (1982, Fig. 8) presented a schematic picture of the basinwide circulation at different depth levels in the eastern North Atlantic. He found no westward flow in the depth range 0-850 $\mathrm{m}$ at the AzCC latitude. The reason is trivial: Saunders developed his pattern primarily from IGY (International Geophysical Year) zonal sections. The only quasi-meridional section between $30^{\circ}$ and $38^{\circ} \mathrm{N}$ is confined to the easternmost basin (cf. his Fig. 1). Pollard and $\mathrm{Pu}(1985)$ also had no chance to resolve the $\mathrm{AzCC}$ because they reconstructed meridional sections from the IGY zonal data, yielding a meridional station distance of about 4 degrees between $36^{\circ}$ and $40^{\circ} \mathrm{N}$. Another paper showing only eastward velocities in the $\mathrm{AzCC}$ area has been published by Olbers et al. (1985), who calculated geostrophic velocity fields for the entire North Atlantic from Levitus' (1982) climatological data. The fact that the AzCC is not present in these data is surely due to Levitus' strong smoothing in his objective analysis scheme, which does not resolve wavelengths shorter than about $500 \mathrm{~km}$ (cf. his Fig. 11). Summarizing, the absence of the $\mathrm{AzCC}$ in several investigations is apparently due to strong smoothing and a lack of meridional sections, that is, insufficient meridional resolution.

In contrast to those numerical models mentioned above, models also exist that do not reproduce the $\mathrm{AzCC}$. This is, on the one hand, due to the fact that many of these models are driven by a simplified wind stress (zonal component only) that does not exhibit the meridional anomalies required for the $\mathrm{AzCC}$ generation. On the other hand, the baroclinic circulation models of Sarmiento (1986) and Smith et al. (1990) and the barotropic model of Greatbatch and Goulding (1989), applying realistic stresses, do not give evidence for the AzCC. This is surely an effect of the large friction coefficients used. The model streamfunction in Smith et al. is "visibly smoother than the Sverdrup streamlines, however, no doubt due to the large value used for the frictional coefficient." For a 2-degree horizontal resolution they used a diffusivity of about $8 \times 10^{8}$ $\mathrm{cm}^{2} \mathrm{~s}^{-1}$ at the AzCC latitude. The same reason seems to hold for Sarmiento's model using a coefficient of 4 $\times 10^{8} \mathrm{~cm}^{2} \mathrm{~s}^{-1}$ for the same resolution. Also, Greatbatch and Goulding describe their friction coefficient as "quite large but necessary to control grid point noise."

The strongest evidence for the existence of the AzCC results from the Sverdrup transport calculation given in the present study. The meridional horizontal volume transport between the surface and some reference depth $H$ is related to the wind-stress curl. The questions remain to what extent this simple linear equation is suitable to describe the ocean volume transport in a reasonable way and what reference depth should be chosen. The validity of the Sverdrup equation has been checked by various authors with different results. Leetmaa et al. (1977) compared geostrophic transports across selected latitudes in the North Atlantic with the Sverdrup relationship and concluded that "we believe that there is a good reason to suppose that the interior transport of the subtropical gyre of the North Atlantic is essentially consonant with the Sverdrup curl-of-thewind-stress relationship." To the contrary, Wunsch and Roemmich (1985) found that, "On a basinwide basis Sverdrup balance is inconsistent with extant estimates of the meridional flux of heat. In the eastern Atlantic one can only say that there is no reason to expect that the Sverdrup balance does govern the meridional transport." In contrast, Böning et al. (1991a) confirmed Sverdrup's relationship and attributed the different findings of Leetmaa et al. (1977) and Wunsch and Roemmich (1985) to neglect of the Antilles Current in both studies, the transport of which contributes significantly to the western boundary current transport. In the same study, Böning et al. (1991a) found 1000 $\mathrm{m}$ to be a reasonable reference depth for Sverdrup transport calculations in the North Atlantic.

Another question is to what extent the Sverdrup flow pattern is modified when using different wind-stress climatologies. This problem has been addressed by Böning et al. (1991b, cf. their Fig. 7), who compare the North Atlantic Sverdrup transport streamfunction based on the wind-stress climatologies of $\mathrm{HR}\left(2^{\circ} \times 2^{\circ}\right.$ horizontal resolution $)$ and $\mathrm{IH}\left(1^{\circ} \times 1^{\circ}\right)$. In particular, in the latitude band between $36^{\circ}$ and $40^{\circ} \mathrm{N}$, the gross features of both Sverdrup flows are similar. The main differences are that east of $40^{\circ} \mathrm{W}$ the $\mathrm{IH}$ transport is directed toward the southwest, in contrast to the nearly westward transport resulting from $\mathrm{HR}$, and that to the west of this meridian HR yields a closed anticyclone, whereas IH does not. However, a recalculation of the IH Sverdrup transport reveals that this is only a matter of contouring; using a smaller contour interval reproduces a closed anticyclone but of somewhat smaller size than in HR. In addition, the presence of the anticyclonic gyre in both climatologies based on different datasets makes it unlikely that this feature is an artifact of the lower-resolved HR climatology.

If we believe in the validity of the Sverdrup transport concept, why has the $\mathrm{AzCC}$ never been mentioned in earlier studies? The following reasons are probably responsible for this deficiency.

- The AzCC is zonal and so was the majority of sections. 
- The $\mathrm{AzCC}$ is not noticeable at the sea surface.

- The $\mathrm{AzCC}$ is narrow and has slipped through lowresolution analyses.

- The $\mathrm{AzCC}$ has been smeared out in climatological datasets due to strong smoothing.

- The $\mathrm{AzCC}$ is due to the fine structure of the windstress field and, therefore, could not be reproduced in numerical models applying simplified sinusoidal windstress patterns.

- The $\mathrm{AzCC}$ has not been reproduced in general circulation models applying realistic wind stress but by using large values for the eddy viscosity.

Let us now return to the starting point of this paperis Worthington's concept correct or not? Worthington's northern gyre requires westward flow at about $40^{\circ} \mathrm{N}$, and one must admit that this matches the AzCC latitude amazingly well. Hence, it is proposed that this concept should not be completely laid to rest. So far, it has been demonstrated only by several investigators that a connection exists between the GS and the NAC-in contrast to Worthington's suggestion of two independent gyres. But there is strong evidence for the existence of these two gyres away from the boundary current region. The northern gyre may be identical with the permanent "anticyclone" or "high pressure cell" found in the surveys of Mann (1967), Clarke (1980), and Krauss et al. (1987, 1990), the special role of which has already been emphasized by Krauss et al. (1987): "The anticyclonic eddy . . . turns out to be a more complex feature than originally assumed."

Finally, what are the implications for the structure of the upper ocean wind-driven circulation of the North Atlantic? Because Sverdrup's theory does not reproduce

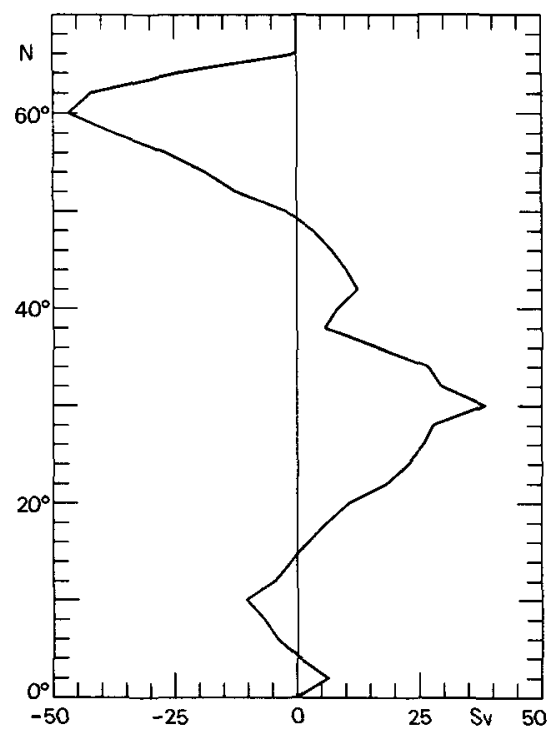

FIG. 9. The western boundary current transport derived from the Sverdrup transport.

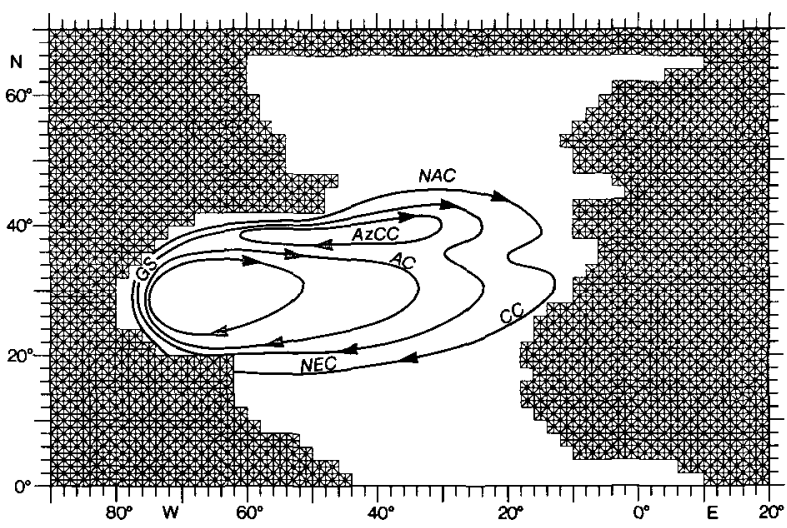

FIG. 10. The wind-driven circulation of the North Atlantic (AC: Azores Current, AzCC: Azores Countercurrent, CC: Canary Current, GS: Gulf Stream, NAC: North Atlantic Current, NEC: North Equatorial Current).

western boundary currents, which are necessary to close the circulation in the ocean interior, boundary current transports were calculated here by applying continuity of horizontal flow at the western boundary. The result is displayed in Fig. 9. The maximum northward transport of about $37 \mathrm{~Sv}$ occurs at $28^{\circ} \mathrm{N}$. Farther north the transport decreases to about $5 \mathrm{~Sv}$ at $36^{\circ} \mathrm{N}$ but then intensifies and reaches $10 \mathrm{~Sv}$ at $42^{\circ} \mathrm{N}$. Finally, farther north, the northward transport decreases to zero at about $40^{\circ} \mathrm{N}$ and turns into southward transport due to the subpolar boundary current. Comparison with Figs. 1, 2, and 3a shows that this reinforcement of the boundary current is caused by the AzCC. The winddriven circulation of the central North Atlantic resulting from this analysis is sketched in Fig. 10. The pattern is consistent with Worthington's concept of a two-gyre circulation in the midlatitude North Atlantic.

\section{REFERENCES}

Böning, C. W., R. Döscher, and R. Budich, 1991a: Seasonal transport variations in the western subtropical North Atlantic: Experiments with an eddy-resolving model. J. Phys. Oceanogr., 21, 12711289.

. and Sverdrup transports in the North Atlantic: A comparison of the Hellerman-Rosenstein and Isemer-Hasse climatologies. J. Phys. Oceanogr., 21, 221-235.

Clarke, R. A., H. W. Hill, R. F. Reiniger, and B. A. Warren, 1980: Current system south and east of the Grand Banks of Newfoundland. J. Phys. Oceanogr., 10, 25-65.

Defant, A., 1936a: Schichtung und Zirkulation des Atlantischen Ozeans: Die Troposphäre. Wissenschaftliche Ergebnisse der deutschen Atlantischen Expedition auf dem Forschungs- und Vermessungsschiff "Meteor" 1925-1927, Band VI, erster Teil. Defant, A., Ed., Verlag von Walter de Gruyter, 411 pp.

- 1936b: Atlas zur Schichtung und Zirkulation des Atlantischen Ozeans. Wissenschaftliche Ergebnisse der deutschen Atlantischen Expedition auf dem Forschungs- und Vermessungsschiff "Meteor" 1925-1927, Band VI-Atlas. Defant, A., Ed., Verlag von Walter de Gruyter, 103 charts.

_ 1961: Physical Oceanography. Vol. I, Pergamon, 729 pp. 
Dietrich, G., K. Kalle, W. Krauss, and G. Siedler, 1980: General Oceanography, 2d ed. John Wiley, $626 \mathrm{pp}$.

Fofonoff, N. P., and R. M. Hendry, 1985: Current variability near the Southeast Newfoundland Ridge. J. Phys. Oceanogr., 15, 963-984.

Gould, W. J., 1983: The northeast Atlantic Ocean. Eddies in Marine Science, A. R. Robinson, Ed., Springer-Verlag, 145-157.

- 1985: Physical Oceanography of the Azores front. Progress in Oceanography, Vol. 14, Pergamon, 167-190.

Greatbatch, R. J., and A. Goulding, 1989: Seasonal variations in a linear barotropic model of the North Atlantic driven by the Hellerman and Rosenstein wind stress field. J. Phys. Oceanogr.. 19, 572-595.

Hellerman, S., and M. Rosenstein, 1983: Normal monthly wind stress the World Ocean with error estimates. J. Phys. Oceanogr., 13, 1093-1104.

Isemer, H.-J., and L. Hasse, 1985: The Bunker Climate Atlas of the North Atlantic Ocean. Vol. 1: Observations. Springer-Verlag, 252 pp.

, and - 1987: The Bunker Climate Atlas of the North Atlantic Ocean. Vol. 2: Air-Sea Interactions. Springer-Verlag, $218 \mathrm{pp}$.

Käse, R. H., and G. Siedler, 1982: Meandering of the subtropical front southeast of the Azores. Nature, 300, 245-246.

- W. Zenk, T. B. Sanford, and W. Hiller, 1985: Currents, fronts, and eddy fluxes in the Canary Basin. Progress in Oceanography, Vol. 14, Pergamon, 231-257.

Kawase, M., and J. L. Sarmiento, 1985: Nutrients in the Atlantic thermocline. J. Geophys. Res., 90(C5), 8961-8979.

Klein, B., and G. Siedler, 1989: On the origin of the Azores Current. J. Geophys. Res., 94(C5), 6159-6168.

Krauss, W., 1986: The North Atlantic Current. J. Geophys. Res., 91, 9739-9748.

—, R. H. Käse, and H.-H. Hinrichsen, 1990: The branching of the Gulf Stream southeast of the Grand Banks. J. Geophys. Res., 95(C8), 13 089-13 103.

- - E. Fahrbach, A. Aitsam, J. Elken, and P. Koske, 1987: The North Atlantic Current and its associated eddy field southeast of Flemish Cap. Deep-Sea Res., 34, 1163-1185.

Leetmaa, A., P. Niiler, and H. Stommel, 1977: Does the Sverdrup relation account for the Mid-Atlantic circulation? J. Mar. Res., $35,1-10$.

Levitus, S., 1982: Climatological Atlas of the World Ocean. NOAA Prof. Paper No. 13, U.S. Department of Commerce, $173 \mathrm{pp}$.

Maillard, C., 1984: Mean circulation and exchanges in the northeastern Atlantic from historical data. Rapp. P.-V. Réun. Cons. Int. Explor. Mer, 185, 131-139.

Mann, C. R., 1967: The termination of the Gulf Stream and the beginning of the North Atlantic Current. Deep-Sea Res., 14, 337-359.

Montgomery, R. B., and M. J. Pollak, 1942: Sigma-T surfaces in the Atlantic Ocean. J. Mar. Res., 5, 20-27.

Olbers, D. J., M. Wenzel, and J. Willebrand, 1985: The inference of
North Atlantic circulation patterns from climatological hydrographic data. Rev. Geophys., 23, 313-356.

Pollard, R. T., and S. Pu, 1985: Structure and circulation of the upper Atlantic Ocean northeast of the Azores. Progress in Oceanography, Vol. 14, Pergamon 443-462.

Richardson, P. L., 1983: Eddy kinetic energy in the North Atlantic from surface drifters. J. Geophys. Res., 88(C7), 4355-4367.

Sarmiento, J. L., 1986: On the North and tropical Atlantic heat balance. J. Geophys. Res., $91(\mathrm{C} 10), 11677-11689$.

Saunders, P. M., 1982: Circulation in the eastern North Atlantic. $J$. Mar. Res., 40 (Suppl.), 641-657.

Semtner, A. J., and R. M. Chervin, 1988: A simulation of the global ocean circulation with resolved eddies. J. Geophys. Res., 93(C12), $15502-15522$.

- and -1992 : Ocean general circulation from a global eddyresolving model. J. Geophys. Res., 97(C4), 5493-5550.

Smith, L. T., D. B. Boudra, and R. Bleck, 1990: A wind-driven isopycnic coordinate model of the North and equatorial Atlantic Ocean. 2. The Atlantic basin experiments. J. Geophys. Res., 95(C8), 13 105-13 128.

Spall, M. A., 1990: Circulation in the Canary Basin: A model/data analysis. J. Geophys. Res., 95(C6), 9611-9628.

Stramma, L., 1984a: Geostrophic transport in the warm water sphere of the eastern subtropical North Atlantic. J. Mar. Res., 42, 537558.

1984b: Potential vorticity and volume transport in the eastern North Atlantic from two long CTD sections. Dtsch. Hydrogr. Z., 37, 147-155.

— temperature fluxes in the eastern North Atlantic. J. Mar. Res., 46, 281-299.

, and T. J. Müller, 1989: Some observations of the Azores Current and the North Equatorial Current. J. Geophys. Res., 94(C3), 3181-3186.

Sy, A., 1988: Investigation of the large-scale circulation patterns in the central North Atlantic: The North Atlantic Current, the Azores Current, and the Mediterranean Water plume in the area of the Mid-Atlantic Ridge. Deep-Sea Res., 35(3), 383413

TOPOGULF Group, 1986: TOPOGULF-A joint programme initiated by IFREMER, Brest and If M, Kiel. Data Report, Vol. 1 , Ber. Institute für. Meereskunde, Kiel, 154, $183 \mathrm{pp}$.

Treguier, A. M., 1992: Kinetic energy analysis of an eddy resolving, primitive equations model of the North Atlantic. J. Geophys. Res., 97(C1), 687-702

Worthington, L. V., 1962: Evidence for a two gyre circulation system in the North Atlantic. Deep-Sea Res., 9, 51-67.

1976: On the North Atlantic Circulation. The Johns Hopkins Oceanographic Studies, No. 6, The Johns Hopkins University Press, $110 \mathrm{pp}$.

Wunsch, C., and D. Roemmich, 1985: Is the North Atlantic in Sverdrup balance? J. Phys. Oceanogr., 15, 1876-1880. 